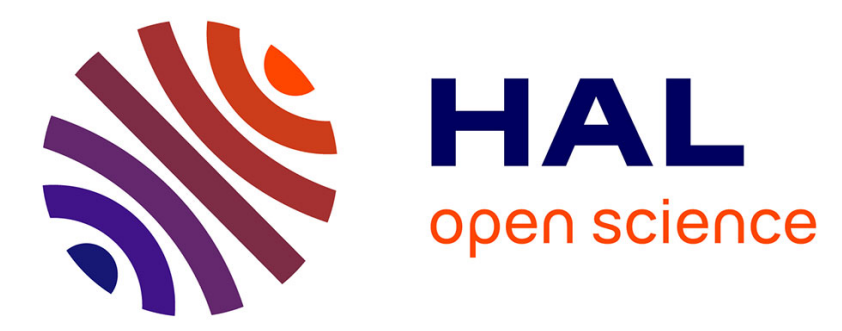

\title{
At the Desk of a Man of Letters: Literate Practices in Byzantine Egypt according to the Dossier of Dioscorus of Aphrodite
}

\author{
Jean-Luc Fournet
}

\section{- To cite this version:}

Jean-Luc Fournet. At the Desk of a Man of Letters: Literate Practices in Byzantine Egypt according to the Dossier of Dioscorus of Aphrodite. Scott Fitzgerald Johnson. Languages and Cultures of Eastern Christianity: Greek, The Worlds of Eastern Christianity, 300-1500, 6, pp.221-248, 2015. hal-01597569

\author{
HAL Id: hal-01597569 \\ https://hal.science/hal-01597569
}

Submitted on 28 Sep 2017

HAL is a multi-disciplinary open access archive for the deposit and dissemination of scientific research documents, whether they are published or not. The documents may come from teaching and research institutions in France or abroad, or from public or private research centers.
L'archive ouverte pluridisciplinaire HAL, est destinée au dépôt et à la diffusion de documents scientifiques de niveau recherche, publiés ou non, émanant des établissements d'enseignement et de recherche français ou étrangers, des laboratoires publics ou privés. 
[in:] S.F. JoHnson (éd.), Languages and Cultures of Eastern Christianity: Greek, Farnham, 2015, p. 221-248.

\title{
At the Desk of a Man of Letters: Literate Practices in Byzantine Egypt according to the Dossier of Dioscorus of Aphrodite
}

\author{
Jean-Luc FOURNET*
}

It is currently impossible to write a history of literature and erudition in antiquity without taking into account the rich and varied testimony of papyri, which are an essential supplement to literary sources. However, while trying to exploit papyri, the historian of literature or, more widely, of culture, can but experience a certain frustration due to the nature of this documentation. On the one hand, literary papyri, in theory more immediately usable sources, inform us essentially on what authors were read or owned - therefore an essentially passive culture - as well as on the techniques and uses for copies of works (material, writing, layout) that is, the culture of copying. On the other hand, documentary papyri sometimes provide us with some limited information on those who were active in this culture, most often anonymously and by way of allusions. Consequently, one can draw, at best, information on the social and material conditions of the presence and diffusion of Greek literature, but it is impossible to relate this to a particular literary work or figure whose work is known. Between the two, papyrologists have established a sort of 'purgatory': 'para-literary' papyri (in English 'sub-literary papyri') that would be most suitable for illustrating an active participation in literary Hellenism if they were not dealing with the most humble, technical, and elementary aspects of Greek literature (textbooks, magic or medical recipes, etc.), where automatic reflexes win over invention, and learning over autonomous practice. The information is not scarce, but it is scattered and does not allow us to grasp the different phases of Greek paideia, in the broadest sense (learning, reading, and production), as interconnected, unless by recomposing texts from varied dossiers of various provenances, periods, and socio-cultural contexts. Furthermore, papyrologists are hardly ever able to place literary papyri in their Sitz-im-Leben, that is, to attribute to a book the context of its owner: a primary condition in order to place literate practices in their social setting. In very rare cases, this contextualisation is possible, ${ }^{1}$ but it generally concerns consumers rather than practitioners of literature. One dossier escapes this categorisation: that of Dioscorus of Aphrodite. II

Dioscorus is one of the great figures of Byzantine papyrology, revealed in 1905 by the discovery of a jar filled with papyri in a village of Middle Egypt named Kûm Ishqâw (previously Aphrodite or Aphrodito). Half of the papyri that the jar contained were embezzled by the village's inhabitants and, via antiques dealers, sold to various European collections (mostly in London, Berlin, Florence, Strasbourg) and American ones (Michigan and Baltimore), while the rest were collected by Gustave Lefebvre, inspector for the Service des Antiquités, and deposited in the Egyptian museum in Cairo. This collection, which is today deemed to consist of roughly 650 texts (not to mention the many unedited ones), contains some literary papyri and a majority of documentary papyri covering most of the sixth century, with Dioscorus as a central figure. The papers composing his documentary archives allow us to

\footnotetext{
* I should like to thank Elodie Turquois for translating and Prof. Adam Bülow-Jacobsen for proofreading this essay.

${ }^{1}$ Cf. in general W. Clarysse, 'Literary Papyri in Documentary "Archives"”, in E. van’t Dack, P. van Dessel, and W. van Gucht (eds.), Egypt and the Hellenistic World, coll. 'Studia Hellenistica', n. 27, Louvain, 1983, p. 4361.
} 
reconstruct his family, career, and background. ${ }^{2}$ Originating from one of the most influential Coptic families in Aphrodite (to the extent of exerting an almost monopolistic authority over the village), Dioscorus managed both his own business as a landowner and that of his village (in the role of protokometes, 'first man of the village'). His existence as a public figure/ gentleman farmer was shaken by the result of troubles with the fiscal administration. These saw him defend his rights in Constantinople (then capital of the Empire) and forced him to settle down for some time in Antinoopolis, the seat of the governor of the Thebaid, where he made a living as a notary. ${ }^{3}$

The jar in Aphrodite also contained fragments of books having belonged to Dioscorus' library, but particularly - and this is what gives this dossier its uniqueness - around 50 poems which he composed, most of them in dactylic hexameters, and more rarely in iambic trimeters. ${ }^{4}$ Apart from a few pieces written on mythological subjects (Achilles and Polyxena, Apollo's passionate love for Daphne), these are mostly epithalamia and encomia addressed to important figures on the occasion, for example, of their taking office or their birthday. These compositions are only preserved in the form of rough drafts, or more polished copies written in Dioscorus' own hand, covering various sheets of papyrus, most often already used on the other side. The final copies sent to the characters praised by the author in verse have evidently not been recovered. As much as we can tell from what is left of them, the poems of Dioscorus were not part of an edition in the modern sense of the term, even by their own author's hand. They are indeed mostly occasional poems, composed mainly in I| periods of crisis and having solely a utilitarian function (praising the authorities who could come to his help): nothing justified gathering them into an edition.

Therefore, the interest of this dossier is not simply in allowing us to place a library in its documentary context, and thus to study the culture of a member of the village élites in a Hellenised province of the Empire, whose historical and social profile is precisely known through the collection of his business papers. Its interest is also in relating an original literary production to, on the one hand, some of the books that influenced and nurtured its author, and, on the other, documentary texts that allow us to grasp his personality, the socio-cultural conditions behind its creation, and the historical circumstances that acted as its impetus. Furthermore, this production is known through the rough drafts written by the author himself: a unique case in the history of pre-medieval Greek philology, at least for non-anonymous authors. All the conditions are hence fulfilled to allow studying, in the most concrete way possible, literary practice in both its passive and active dimensions: reading, studying and copying authors, but also composing texts considered as literature. We shall see that in Dioscorus' case it is not limited to these two aspects, but that his role as a man of letters led him to practice as a schoolmaster and a notary, something that not only completes the picture of literate practices in the Byzantine period, but also characterises the essence of Hellenism in late antique society.

With Dioscorus, the Greek culture of a certain social background is revealed: not that of an exceptional figure, a genius of literature or erudition, but that of an average man of letters, belonging to the Greek-speaking élite of a village in a province of the proto-Byzantine empire. It is precisely his quality of being average that makes him exemplary and representative of the vast community of small provincial men of letters that the household names, bolstered by

\footnotetext{
${ }^{2}$ These were published principally by J. Maspero in the three volumes P. Cair. Masp.

${ }^{3}$ On the life and background of Dioscorus, see the excellent studies of J. Maspero, 'Un dernier poète grec d'Égypte: Dioscore, fils d'Apollôs', Revue des Études Grecques, n. 24, 1911, p. 426-81, and of H.I. Bell, 'An Egyptian Village in the Age of Justinian', Journal of Hellenic Studies, n. 64, 1944, p. 21-36. See also more recently L.S.B MacCoull, Dioscorus of Aphrodito. His Work and his World, Berkeley, 1988.

${ }^{4}$ The translated and commented edition of the complete poems can be found in my Hellénisme, I, p. 239-458, and II, p. 459-665.
} 
literary sources and tradition, have eclipsed. And at any rate, what interests us here is less the work itself than how it came to exist; it is not its intrinsic quality, but rather the set of practices that condition the relationships between man and book, between man and the culture of writing, relationships that can in certain cases be expressed in literary creation.

\section{DIOSCORUS THE READER: A MAN OF LETTERS AND HIS BOOKS}

A man of letters cannot be conceived of without his library, his first tool, especially in the imperial period where bookish culture become increasingly important in ways which Dioscorus' example will highlight. Few libraries in antiquity (private, of course) have survived, with the notable exception of the Villa of the Papyri in Herculaneum. The clandestine nature of the majority of papyrological discoveries, or the basic state of excavations, have more often than not muddled the stratigraphic data which allow literary papyri either to be placed in the original setting of the $\|$ cluster they were a part of (the library), or to be linked to documentary archives that throw light on their owner. Yet this is essential in order to study the relationship between a man of letters and his books which is the first stage of our investigation of literary practices.

\section{INVENTORY OF THE LIBRARY}

Even though the discovery of the Aphrodite jar was in part clandestine, we have at our disposal all the elements necessary for such a study. Indeed, one must immediately point out the fact that Dioscorus' library is only partially known: the jar contains only selected material. We do not know who was responsible for such a choice, but it is likely that it happened after Dioscorus' death. The contents of the jar offer a testimony on the state of his library after his death; it could have contained works he abstracted during his life or that his heirs continued using. The complete absence, for example, of Christian texts could very well be explained by the fact that Dioscorus was the curator at a monastery founded by his father, Apa Apollos, and where it is not impossible that he himself retired - although we do not have any proof. If Dioscorus himself possessed Christian books, those may have become part of the monastery's own library, unless they had been judged useful and hence kept by the heirs, as opposed to the works of classical literature, relegated to the jar. ${ }^{5}$ At any rate, the books which have reached us, even if they represent merely part of the initial library - and all the more so of his reading - correspond to the authors that made the biggest impact on him, and, because of this, they can legitimately be considered revealing for the literary personality of Dioscorus. ${ }^{6}$

The list of literary and sub-literary texts in his library are the following. ${ }^{7}$

\section{A. Not copied by Dioscorus}

1. A codex, originally unabridged, of Homer's Iliad (plate 1).

2. A codex of Scholia Minora, which covered the whole of the Iliad.

3. A codex of Menander's comedies.

4. A codex of ancient comedies containing, among others, Eupolis' Demes. II

\footnotetext{
${ }^{5}$ One can find a sign of this indifference, or even this contempt for non-Christian literature, in the fact that the precious codex of Menander had previously been dismembered and only about a quarter of it had been placed in the jar, crumpled in its upper section, as if to be used as a stopper! As far as the story of its discovery is concerned, one needs to consult the few lines G. Lefebvre wrote in the preface to his Fragments d'un manuscrit de Ménandre, Cairo, 1907, p. VIII-XI.

${ }^{6}$ The three main writers missing are Euripides, Pseudo-Apollinarius of Laodicea and Nonnos, whose influence is very present in Dioscorus' work (cf. Hellénisme, II, p., 667-80).

${ }^{7}$ For more details, see my Hellénisme, II, p. 669-70.
} 
5. A codex of the conjugation of the contract verbs $\pi$ oi $\hat{\omega}, \beta$ ô and $\chi \rho v \sigma \hat{\omega} .^{8}$

6. A roll of contract verb conjugations and various folios containing extracts from the same conjugations, all written in the same hand.

7. A metrological table, giving correspondences between various measures (unedited).

8. A medicinal recipe copied at the bottom of a blank page in a documentary codex.

\section{B. Copied by Dioscorus}

9. A double-sided folio containing a Life of Isocrates and some terse rhetorical notes.

10. A poem on the Pan-Hellenic games, Palatine Anthology, IX, 357.

11. A Greek-Coptic glossary compiled on the back of a petition.

12. A metrological table similar to $n .7$.

13. A phylactery against evil spirits on the back of a contract.

14. A collection of documentary pieces (a petition, two letters and a document of indeterminate nature) copied for their literary interest.

\section{THE READER'S IMPRINT}

Two main pieces of information can be drawn from this list. Firstly, the active participation of a man of letters in his library. This evidently starts by acquiring works, a task which in the context of antiquity is less than simple and sometimes requires great effort. Books are precious objects, due to the work required in their production and the difficulty that can be experienced in acquiring them or in obtaining a copy to reproduce. It is thus that they are piously preserved from generation to generation, the objects of meticulous care that expresses itself, amongst other things, in regular material maintenance. The books owned by Dioscorus do not escape this rule. Of the four main works which have reached us through his library, three were already in his time ancient texts: the codex of Menander and that of ancient comedies dated from the previous (fifth) century; as for the codex of Scholia, it was copied at the turn between the fourth and fifth centuries. Some wear and tear of the book resulted from this, affecting both the materials of the book and the ink. If the state of conservation of these fragments did not allow detection of any repairs to the binding or gatherings, the codex of the Scholia however offers many clues indicating wear and tear in the text itself: the ink has sometimes lost its freshness to such a degree that one of the last owners || (Dioscorus?) had to rewrite over some letters of words in the original text that had become either illegible or too faint. ${ }^{9}$

But it is mostly through the copying of texts itself that the active relationship between the man of letters and his library expresses itself. Thus Dioscorus copied a Life of Isocrates, a poem from the Anthology, a phylactery, in addition to compiling a Greek-Coptic glossary, and putting together an anthology of documents of various provenances and nature, but all having a literary significance. This copying work nevertheless is limited here to technical works, handbooks and isolated short pieces (which, in the case of Dioscorus, could belong to a teaching activity to which I will return later): it is indeed these types of texts that existed solely as private copies. But Dioscorus did not have someone else copy them for him: he dealt with it himself, which is not insignificant in terms of understanding his cultural profile.

The involvement of a man of letters in the creation of his library often takes a more reflexive turn, but perhaps more essential in that it is the basis of any written intellectual work, and it also has considerable consequences for the transmission of texts: the correction and

\footnotetext{
${ }^{8}$ P. Aphrod. Lit. III 1, which is completed by several unedited fragments from Corpus Christi College (Cambridge) and a papyrus in Berlin edited by H. Harrauer and P.J. Sijpesteijn, Neue Texte aus dem antiken Unterricht, MPER NS XV, Vienna, 1985, n. 139 (p. 130-31). This codex, now complete, will receive a new edition by myself.

${ }^{9}$ Cf. P. Aphrod. Lit. II, p. 96.
} 
annotation of his books. This double intervention of the man of letters in his books is well illustrated through part of Dioscorus' library.

Correction, or diorthosis, is a phase in the production of a work: the work of the copyist is indeed followed by that of the diorthotes who re-reads, collates the copy with its model or eventually another specimen, and corrects accordingly. Yet this work continues during the entire lifespan of one copy according to its various owners' wills, owners who can modify the text depending on their erudition or after consulting critical texts or different copies. Hence the copy of the Iliad in Dioscorus' library bears the mark of this critical activity. ${ }^{10}$ The codex was copied in the sixth century by a hand that was also responsible for the punctuation, apostrophes, tremas, as well as paragraphoi showing the structure of the text. This copy did not remain as it was: various people (as far as one can judge from the variety of the handwritings and the inks) intervened upon it, while systematically adding accents and breathings, adscript iotas, and correcting some readings. The first series of interventions aimed to render more legible and easier to consult the text written, as was the custom in Antiquity, in scriptio continua, a source of misreading and ambiguities. It proves that this text was diligently read and conceived as an object of repeated readings - perhaps in an educational context, as we shall see, and not as a display copy.

The second series of interventions belongs to another type of work, which is not entirely separate from the first. The material conditions of the production and diffusion of texts in Antiquity forced the man of letters to do philological work which went beyond simply tracking down copying mistakes. Homer's text, for example, transmitted and hence altered for more than a millennium, posed a certain amount $\|$ of problems that required, prior to copying, some textual criticism: the correction of copying mistakes or of readings judged inferior after collating with another copy. Dioscorus' copy itself also bears witness to this work of diorthosis (plate 1): almost all of the lapsus calami have been amended (apart from minor mistakes of accentuation or phoneticism); a variant, rightly judged erroneous, has been replaced by another in II, 560; an athetised verse (II, 558), according to a tradition going back to Aristarchus, has been restored in the upper margin. But these interventions had the potential to be unfortunate: a hand erased three times $(\mathrm{X}, 380,385$; XI, 668) the correct text and replaced it with flawed variants that belong to the category of lectiones faciliores, and show the limits of this philological ability. II

It is impossible to define the amount of responsibility Dioscorus had in these interventions. There is however one firm case in which this philological work was done by him: in a letter which he copied, probably as a template, there was a quotation from Iliad VIII, 539: ' $\dot{\theta} \theta$ '́v $\alpha \tau$ c

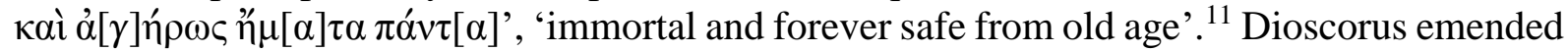
this text later, replacing the contract form (attested in some medieval manuscripts) with the

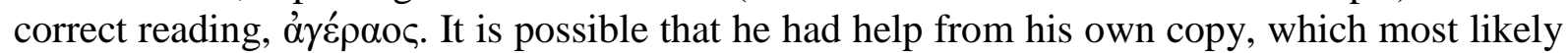
contained the correct text - something that the loss of book VIII makes it impossible to verify.

The man of letters does not satisfy himself solely with correcting books; he also annotates them. This is particularly well illustrated by the copy of the Minor Scholia to the Iliad that Dioscorus owned. ${ }^{12}$ This work presents itself as a glossary of difficult words within Homer's work: the Homeric lemma is followed here by a synonym and/or a grammatical or encyclopaedic explanation. Several readers (among whom was perhaps Dioscorus) have introduced in the margins of this copy many additional glosses. Here is one example among many, extracted from book V, verse 253 (I underline the addition by a second hand here):

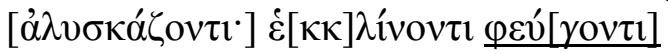

\footnotetext{
${ }^{10}$ For details, see the description of P. Aphrod. Lit. I, Hellénisme, I, p. 16-38.

${ }^{11}$ P. Cair. Masp. III 67295, III, 2.

${ }^{12}$ P. Aphrod. Lit. II.
} 
This addition, and the others from this copy, is not due to the reader's flight of fancy. It is most certainly extracted from another copy of the Minor Scholia offering different explanations. Hence, $\dot{\alpha} \lambda v \sigma \kappa \alpha ́ \zeta o v \tau \imath$, 'shunning', a strictly poetic word, is glossed by a prosaic equivalent, $\dot{\varepsilon}[\kappa \kappa] \lambda i ́ v o v \tau 1$. This gloss is attested in other collections of minor scholia to the Iliad, such as, for example, the Lexeis homerikai. ${ }^{13}$ At a certain time, the possessor of the book decided to add another synonym, $\varphi \varepsilon v$ [ $\gamma$ ov $\tau 1]$, 'fleeing', which he may have found in another collection; it is indeed this term which is used, for example, in ancient prose paraphrases of the Homeric poem. ${ }^{14}$ The interest of this example is in its exposing of the process at play in the making of these collections which, through copying, get expanded in new ways. This is how the first-hand scholium and the second-hand scholium in our example are found side by side in the Scholia of Didymus, a collection of minor scholia transmitted by the Byzantine manuscript tradition. ${ }^{15}$ One can see here how sometimes the annotating work of a man of letters can have a lasting impact on the tradition of a text. II

\section{LIBRARIES AND CULTURAL TRENDS}

The second piece of information that can be gathered from the study of Dioscorus' library is its content. Very few authors can be found in it: Homer, Menander, Eupolis, and, indirectly in the form of a biography, Isocrates. However, more numerous are the compendia, anthologies, handbooks and other practical works. Indeed, as I have mentioned, one can only draw conclusions based on what had been put into the jar. But I find it significant that the only authors whom Dioscorus felt the need to pay homage to in his verse would precisely be the ones represented in what remains of his library: Homer, Menander and Isocrates. ${ }^{16}$ This two-fold observation is typical of the culture of his time. Indeed one witnesses a reduction of the scope of authors and works read: some authors fall into complete oblivion, while others see the part of their work that is still read and transmitted reduced by drastic selections and anthologies. ${ }^{17}$ These selections were mostly at work in schools and would play a decisive part in the survival of ancient literature - that is, what one might call the 'educationalising' of literary culture. Yet Dioscorus is himself an exception to this as he still read and appreciated Menander in the sixth century, at a time when, according to papyrological sources, Menander was becoming increasingly rare in favour of Aristophanes, who would become the premier comedy writer leading to the complete disappearance of Menander. ${ }^{18}$ Aside from this anachronism, his library, with its limited number of works and particular focus on Homer, demonstrates accurately the increasingly reduced literary choices of the period, as well as the evident reduction in the production of books.

This state of proto-Byzantine culture is the result of a new relationship with literature as much as it is the cause of it. The choices of literature are mostly, as I have already mentioned, made in relation to the educational system, which preserves of the Greek literary inheritance

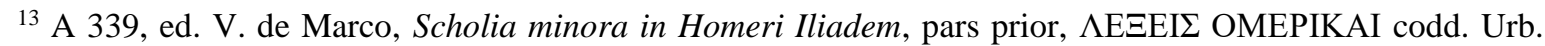
CLVII et Selestadiensis CVII (sic for CV), fasc. 1, Vatican, 1946.

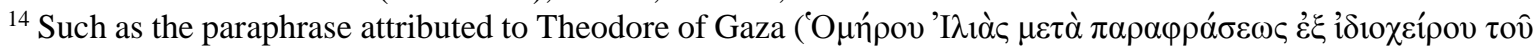

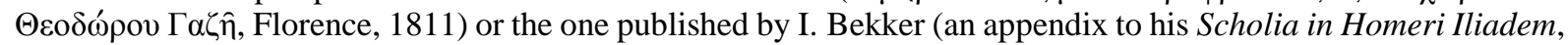
Berlin, 1825).

${ }^{15}$ Ed. J. Lascaris, Homeri interpres pervetustus, Rome, 1517.

${ }^{16}$ Homer (P. Aphrod. Lit. IV 4,22; 6,11; 9,4); Menander (P. Aphrod. Lit. IV 4,7); Isocrates (P. Aphrod. Lit. IV 4,8). I am voluntarily omitting Solon (P. Aphrod. Lit. IV 11,12;18,21; 19,6), because he does not appear in Dioscorus as a poet, but as a lawyer.

${ }^{17}$ In the vast bibliography, I cite only the recent study by H. Maehler, 'Byzantine Egypt: Urban Elites and Book Production', Dialogos, n. 4, 1997, p. 125-9.

${ }^{18}$ For a list of Menander papyri, cf. P. Mertens, 'Les témoins papyrologiques de Ménandre. Essai de classement rationnel et esquisse d'une étude bibliologique', Serta Leodiensia Secunda, Liège, 1992, p. 331-56 (cf. in particular p. 351, where the number of codices for Menander is compared to the number of codices of Aristophanes). On the reception of these two authors, cf. recently A. Blanchard, 'Destins de Ménandre', Ktema, n. 22, 1997, p. 213-25. 
only what it judged most suitable to shape the youth and to instil in it the rules of reading and writing well. Hence the great literary authors are appropriated for utilitarian purposes: Menander and Homer become two masters of oratory; they are read as if they were rhetorical |l handbooks and considered models to emulate. ${ }^{19}$ It is in this manner that, in one of his poems, Dioscorus praises the eloquence of a senior official in Constantinople by comparing him to Menander and Homer. ${ }^{20}$ As I have written regarding this poem, it 'sums up fairly well the literary values of a period that has reclaimed for rhetorical purposes two poets, one epic, the other comic, masters, of hexameters for the former, of trimeters for the latter, two authors constituting, in a word, a synopsis of literary creation. This appropriation of the works of Homer and Menander by the field of rhetoric lends more significance to the simultaneous presence of the Homeric and Menandrean codices in Dioscorus' library, as they were thought of as rhetoric handbooks above all else. In a society where creation happens by way of rhetoric, the literary heritage is put to work in the service of the latter. It is invested with a practical mission: to educate and to facilitate creation. This idea of a functionality and of appropriation for personal purposes [...] appears to account for the whole of [Dioscorus'] library: far from trying to trigger and maintain the pleasure of reading (viewed as gratuitous), it brings together practical works (conjugations, glossaries, metrological tables), models (P.Cairo Masp. III 67295), and in particular works considered as handbooks for scholastic purposes only'. ${ }^{21}$ One sees that an ancient library is not necessarily the place for delicate literary and intellectual enjoyment, but the receptacle of reference works destined to be of use.

\section{DIOSCORUS THE SCHOOLMASTER: THE SHARED FATE OF LITERATURE AND EDUCATION}

The importance of education in the literary choices of late antiquity that shape, as we have just seen, the profile of private libraries, also expresses itself in the appearance of the figure of man of letters-grammatikos (secondary school master). ${ }^{22}$ This figure became increasingly prominent in the late empire to the point that it sums up, maybe better than any other, the cultural options of this period. II

\section{DIOSCORUS GRAMMATIKOS}

Even though nothing in his documentary archive proves this formally, it is likely that Dioscorus assumed an educational role. In order to confirm this we have only his library which, examined closely, provides many clues in favour of this hypothesis. ${ }^{23}$ The first series of clues pertains to the nature of part of the texts which make up the library - practical handbooks that can well be imagined in an educational setting. The simultaneous presence of various specimens, resulting from two different hands, of the same tables of contract verbs (in the form of a codex, a roll or separate folios) strongly suggests that Dioscorus would have been teaching Greek to at least

\footnotetext{
${ }^{19}$ This phenomenon begins first and foremost in the imperial period. For Homer, cf. J.-F. Kindstrand, Homer in der zweiten Sophistik, coll. 'Studia Graeca Uppsaliensa', n. 7, Uppsala, 1957, p. 199-203; A. Michel, 'Rhétorique, critique poétique: à propos d'Homère', in R. Chevalier (ed.), Colloque sur la rhétorique - Calliope I, coll. 'Caesarodunum', n. XIV bis, Paris, 1979, p. 1-17; and as an illustration, Lucian's Eulogy of Demosthenes. For Menander, cf. A. Garzya, 'Menandro nel giudizio di tre retori del primo impero', Rivista di Filologia e d'Instruzione classica, n. 37, 1959, p. 237-52.

${ }^{20}$ P. Aphrod. Lit. IV 4,7: 'wise as the old Menander in the art of speech'; 22: 'I see in you a new Homer'.

${ }^{21}$ Hellénisme, II, p. 687.

${ }^{22}$ Cf. most recently, R. Cribiore, Writing, Teachers and Students in Graeco-Roman Egypt, Atlanta, 1996 (amongst other passages, p. 13 with bibliography) and Gymnastics of the Mind. Greek Education in Hellenistic and Roman Egypt, Princeton, 2001 (particularly p. 53-6).

${ }^{23}$ Hellénisme, II, p. 688-90.
} 
two students; ${ }^{24}$ moreover, they date from a period when he himself would not have needed to learn Greek conjugations, as the documents he was then able to write demonstrate. As for the metrological tables, the discovery I made in Berlin of another specimen written in a hand different from that of Dioscorus, containing more mistakes than the one in his hand, makes one think that we have here the original and the copy made by a student. Finally, there are also among the occasional poems of Dioscorus some pieces that seem the be the odd ones out: they are short poems on Greek mythological subjects, centered, aside from one piece on the frustrated loves of Apollo with Daphne and Hyacinth, on the Homeric hero par excellence, Achilles. ${ }^{25}$ These are almost exclusively ethopoeias, a type of composition in which one lends to a character in particular circumstances a speech which has to be in accordance to his personality, as the title of one of them illustrates well: 'What words would Achilles utter while dying because of Polyxena' ${ }^{26}$ Further, ethopoeia belongs to the progymnasmata or 'preliminary rhetorical exercises' that were taught at school and used as models by students in their compositions.

Briefly, just as a part of the library and works of Dioscorus would fit well within the functions of a grammatikos, another part offers clues that it was being used for educational purposes. I am thinking above all of his Iliad and his Scholiae: this would explain the fact that the entire text of the Iliad was provided with accents and breathings. This is where, in the context of antique book production, one finds the presumption of an educational use. Additionally, I have mentioned earlier some unfortunate corrections introduced in the poem's text, indicating a limited critical ability, perhaps due to the young age or inexperience of their author(s). Finally, it is worth noting that these corrections as well as most of the others are found in book X and XI, as if the latter had been the object of more in-depth study. The same goes for the book of Scholia: although we have, at least partially, the scholia for books II, IV, V, XVIII$\mathrm{XX}$, only the pages devoted to book $\mathrm{V}$ have been provided with $\|$ annotations, as if this book had been selected for studying. And it is no coincidence that it was precisely the most appreciated book of the Iliad and therefore one that would be expected to be studied as a priority in school. It is also possible that the two works, the Iliad and the Scholia, would have been used together in this study of the Homeric poem and that the annotations of the Scholia's codex would have corresponded to an increased frequency of corrections in the Iliad's text, but one cannot judge this since the preserved fragments of both works do not overlap.

\section{THE MAN OF LETTERS AS TEACHER: A CHARACTERISTIC AMBIVALENCE}

I therefore believe it is entirely plausible that Dioscorus would have carried out educational functions in a private setting, perhaps strictly within his family. This is in fact a characteristic feature of many other proto-Byzantine men of letters, who had been grammatikoi like him. What interests me here is to see, beyond the anecdotal figure of Dioscorus, what explains this pedagogical role of the man of letters and what it reveals of this period's culture.

Some socio-economic reasons can partially account for this situation. Ancient education, at least in its early stages, was private. Thus it is normal that in a provincial setting, and furthermore in a village, often deserted by itinerant schoolmasters looking for more advantageous situations, the person who was judged the most literate would have taken on the functions of teacher, all the more so in the context of his own family. Additionally, it is also for the man of letters a position that allows him to provide for his own needs, when he does not have the fortune - which was the case for many - of being able to subsist from his literary creations. But such a situation was always prevalent and is in no way characteristic of late antiquity.

\footnotetext{
${ }^{24}$ Hellénisme, I, p. 233-7.

${ }^{25}$ P. Aphrod. Lit. IV 41-6. cf. Hellénisme, I, p. 275-6.

${ }^{26}$ P. Aphrod. Lit. IV 42.
} 
The fact that Dioscorus was a poet and that he, like many other poets of the fourth and fifth century, devoted himself to teaching, draws attention to another phenomenon: that of the fundamental role given to poetry starting from the fourth century, to the point that the teaching of literature and grammar happens almost solely through it. School focuses itself almost exclusively on the study of poets (Homer in particular, but also Euripides and Menander, who, even after his fall from grace, continues to survive by way of selected sentences). It is in fact the poetic form that prevails in rhetorical exercises (progymnasmata): thus one sees the development during this period of the trend of verse ethopoeias, descriptions (ekphraseis), or eulogies (encomia). ${ }^{27} \mathrm{~A}$ grammatikos must therefore be proficient in verse and likewise a poet is also not only able to teach literature, but is the perfect fit for composing poems that will serve as models in the manner of the progymnasmata for the students. This crossing of skills must necessarily have led poets and grammatikoi to merge; || and indeed the proto-Byzantine period saw an expansion of grammatikoi-poets, which the seminal study by Alan Cameron demonstrated and examined well. ${ }^{28}$ Further, this phenomenon considerably modifies the nature of literary production, which is increasingly shaped by the categories of the progymnasmata and rhetorical guidelines. ${ }^{29}$ The poetic works of Dioscorus are, in this respect, paradigmatic.

\section{DIOSCORUS THE POET: THE MAN OF LETTERS AT WORK}

It took a long time for Dioscorus' poetry to be seen as something other than the decadent production of a Copt with barbaric Greek. ${ }^{30}$ This epistemological block, the reasons for which are various and mostly belong to the general misunderstanding which surrounded the art forms of late antiquity for a long time, was overcome during the past 20 years, although it can be said that some may have fallen into the opposite extreme. It is nonetheless because these poems are devoid of poetic genius that they are representative of Greek culture in the proto-Byzantine period put into practice, not by a great, original, and innovative poet, but by an average man of letters, imitating what was done in his period. As for their aspect, their autograph nature allows us to apprehend, without the altering mediation of a copy by another hand, a plethora of concrete facts belonging to two fundamental phenomena: writing practices as well as composition and

${ }^{27}$ See for example the ethopoeias of the Codex of Visions of the Bodmer collection (recently edited by A. Hurst and J. Rudhart, Papyri Bodmer XXX-XXXVII, Munich, 1999). Cf. J.-L. Fournet, 'Une éthopée de Caïn clans le Codex des Visions de la fondation Bodmer', Zeitschrift fiir Papyrologie und Epigraphik, n. 92, 1992, p. $253-66$.

28 'Wandering Poets: A Literary Movement in Byzantine Egypt', Historia, n. 15, 1965, p. 470-509, and in particular p. 492-7. Cf. also R.A. Kaster, Guardians of Language: The Grammarian and Society in Late Antiquity, Berkeley, 1988.

${ }^{29}$ See for example T. Viljamaa, Studies in Greek Encomiastic Poetry of the Early Byzantine Period, coll. 'Commentationes Humanarum Litterarum Societas Scientiarum Fennica', n. 42/4, Helsinki, 1968, p. 13-24 and 98-131; A. Garzya, II mandarino e il quotidiano. Saggi sulla letteratura tardoantica e bizantina, coll. 'Saggi Bibliopolis', n. 14, Naples, 1983, p. 75-112 ('retorica e realta nella poesia tardoantica'); and, for Dioscorus, Hellénisme, I, p. 258-77.

${ }^{30} \mathrm{I}$ am referring to the judgment of the first editor, J. Maspero, 'Un dernier poète grec d'Égypte: Dioscore, fils d'Apollôs', Revue des Études Grecques, n. 24, 1911, p. 426-7 and 472: 'Le poète dont je m'occuperai dans cette étude n'ajoutera rien, j'en ai peur, a l'éclat de la littérature grecque. C'est un obscur versificateur [...]. Une traduction rigoureuse en est impossible: tout au plus, en certains cas, ai-je pu songer à une paraphrase. Le style est flou, les expressions inadéquates à l'idée, la construction grammaticale souvent insaisissable. Les mots, jetés parfois comme au hasard, suggèrent le sens plus qu'il ne l'expriment [...]. En certains endroits, les phrases sont si obscures qu'on peut se demander si l'auteur s'est compris lui-même [...]. L'absence totale d'imagination poétique est l'un des traits distinctifs de l'écrivain, avec ses platitudes boursouflées et ses bizarreries de décadent.' W. Schubart and U. Wilamowitz however - to whom one cannot but attribute a certain literary flair - when they published for the first time in 1907 a poem by Dioscorus, concluded: 'Denn das Gedicht hat Inhalt, es ist mehr wert als ein verständliches Elaborat der Imitation’ (Berliner Klassikertexte V /1, p. 126). 
writing technique. In fact, what Dioscorus' rough drafts help us see is how a text was written and laid out. ||

\section{THE POET AT WORK}

Let us start by giving an example of such a rough draft. I have chosen the epithalamion for Callinicus, duke of the Thebaid, composed in 567 or between 568 and 573 (plate 2): ${ }^{31}$

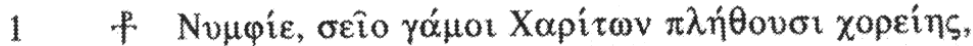

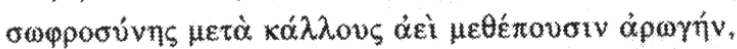

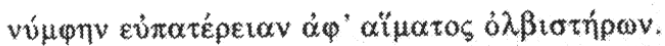

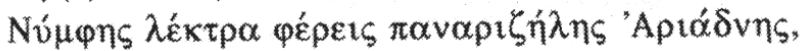

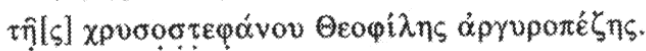

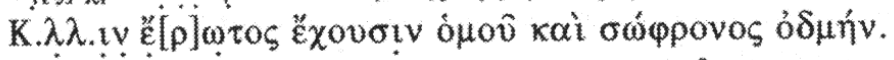

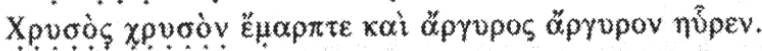

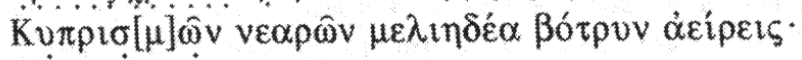

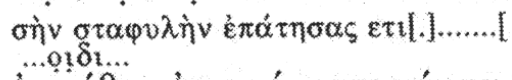

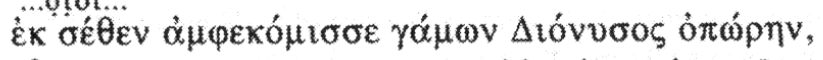

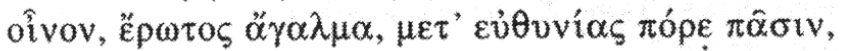

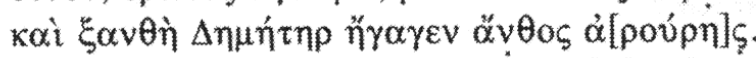

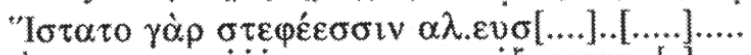

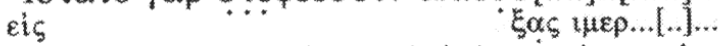

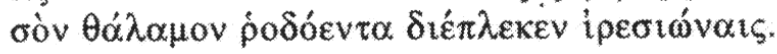

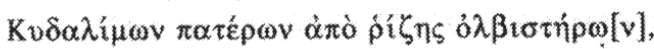

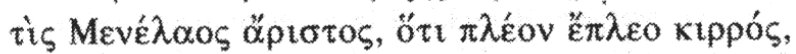

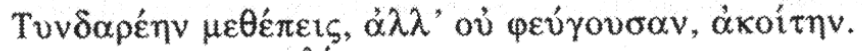
$\lambda \dot{\varepsilon} \kappa \tau p \alpha$

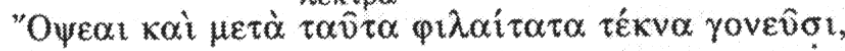

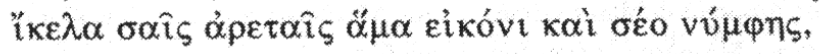

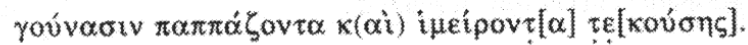

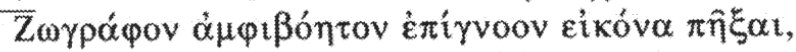

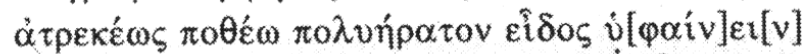

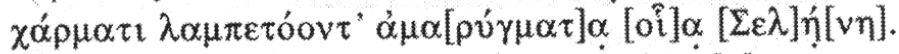

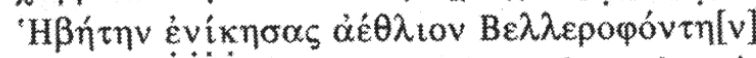

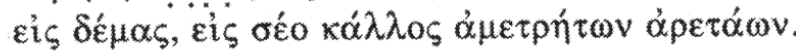

"ónoítos oủk

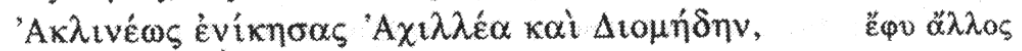

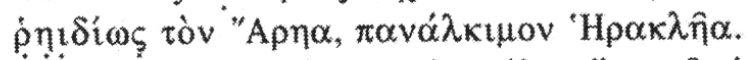

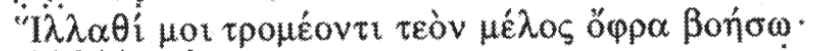

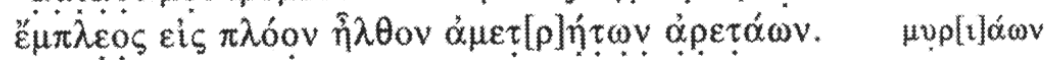

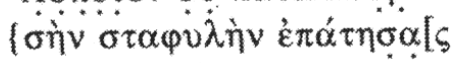

$+\quad$ Tí $\pi \lambda \lambda_{\text {ćo }} . . .[$

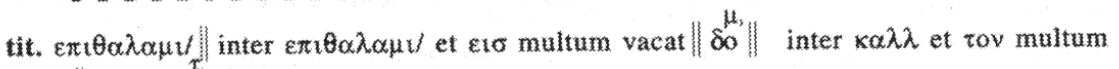

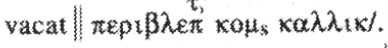

A 3 in margine dextro scriptum | 6 Exovoiv: 1 post corr.? 9 in margine dextro scriptum | 10

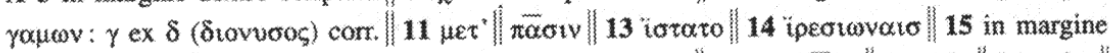

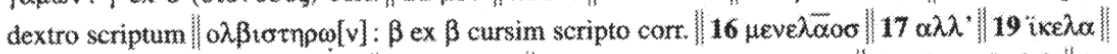

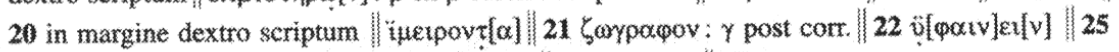

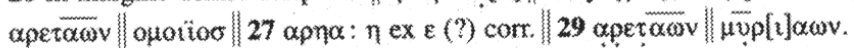

\footnotetext{
${ }^{31}$ P. Aphrod. Lit. IV 32 A.
} 
II

O bridegroom, your nuptials are filled by the Graces' round dance. They unite forever chastity and beauty in your bride of noble birth and of a family that yields prosperity. You are taking for wife a wholly enviable Ariadne, the gold-crowned and silver-footed Theophile. This union has [...] of love and the odor of chastity [?]. Gold has taken gold, silver has found silver. It is a wine grape, sweet like honey and in its youthful bloom, which you are plucking. You are trampling your grapes [...]. In your honour, Dionysus brought the fruit destined for nuptials: he has distributed wine, the ornament of love, in abundance for everyone. And the blonde Demeter brought the flower from her fields. Here! Indeed, crowned [...] has plaited ${ }^{32}$ [garlands] for your nuptial chamber that smells of roses. Coming from a lineage of glorious ancestors, purveyors of prosperity, you are an excellent Menelaus, since you are blonder and you $\|$ are taking for wife a daughter of Tyndareus, who herself does not flee. ${ }^{33}$ And you shall see the fruits of this union, ${ }^{34}$ children so beloved of their parents who, by their virtues, will be your portrait and that of your wife and who, on your lap, will call you 'daddy' and ask for their mother.

I sincerely wish that a renowned painter make a portrait of your likeness, that he render the pleasant beauty in your features, similar to the Moon's splendour that radiates from joy. You have surpassed the young and victorious Bellerophon. In stature, in beauty, no one else equals you. ${ }^{35}$ You have surpassed, without swaying, Achilles and Diomedes, without effort, Ares and the all-powerful Heracles. Be indulgent towards me as I tremble to sing your praise. I have launched myself on the sea of your virtues without number. ${ }^{36}$ You [...] according to principles that do not obey the order here below [...].

One can see in the text of the first draft (sometimes corrected calamo currente as the apparatus criticus shows) that a multitude of later modifications has been added, which I have edited in a smaller font in order to exhibit them better. These are either corrections (which I have put in their respective places from the original) or added verses (which I have inserted for more convenience in the place where they should be in the text, their actual position on the papyrus being indicated by the critical apparatus). ${ }^{37}$

One of these autographs' interests is to expose the original and graphic creation of modifications that an author can perform on a text he is in the process of composing. Dioscorus hence corrects in several ways, according to the nature of the correction and where it appears (I will illustrate each case with examples borrowed from the epithalamion of Callinicus).

- In order to replace:

- when he is in the process of writing his first draft, he proceeds by overwriting, something that happens in general only for very brief sequences of one or two letters. As a general rule, these are corrections written calamo currente and are various in nature: some correct pure lapsus calami, others relate to certain tendencies that Dioscorus is struggling with (mainly the confusion between o and $\omega$, whose quantitative difference

\footnotetext{
${ }^{32}$ An addition above the line has corrected part of this verse, although it is not possible to account for it entirely: '[...] has plaited' seems to have been replaced by 'you have plaited'.

${ }^{33}$ Or, according to a per litteras suggestion of Francis Vian: 'you are taking a daughter of Tyndareus, who, herself, does not flee her husband'.

34 Text before correction: 'after this'.

35 Text before correction: 'You have surpassed the young and victorious Bellerophon with your stature and the beauty of your innumerable virtues'.

36 Text before correction: 'of your innumerable virtues'.

37 The reader can refer to my Hellénisme, I, p. 291-7, where a systematic study of these corrections and additions can be found.
} 
II was no longer naturally experienced by the fourth century) or relate to metrics; these interventions can sometimes concern the graphic aspect of a letter, the initial shape of which he was not satisfied with (such as in verse 15, where he immediately rewrites the beta); finally, a good amount of these corrections throw light on the hesitations of a thought trying to express itself, of a writing in process: for example, in verse 10, he anticipates $\Delta$ tóvvбoç by writing the first letter and then changes his mind and writes

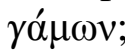

- when he is correcting after writing, he proceeds most often by adding, sometimes above the line (verses 10,16,18), sometimes in the margin (verses 25, 29) without crossing out the sequence to be replaced. This type of correction is the most frequent, used either for a fragment of a word (verse 16), one or several words (verses 16, 18, 25, 29), or a whole verse. As opposed to corrections made calamo currente, these pertain to less simple mistakes. Hence he corrects mistakes of syntax (verse 14), ${ }^{38}$ vocabulary or metrics. Better still, he is more often than not making improvements of a stylistic order: in verse 18, he replaces the flat and vague $\mu \varepsilon \tau \dot{\alpha} \tau \alpha \hat{v} \tau \alpha$, 'after this', with the less

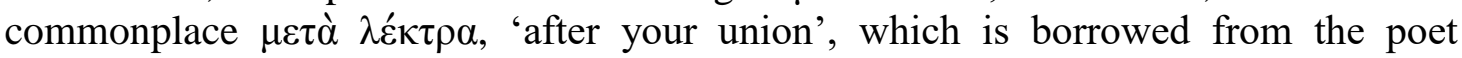
Nonnos; in verse 29 , he replaces the adjective $\alpha \mu \varepsilon \tau[\rho] \hat{\eta} \tau \omega v$, 'innumerable', already used in verse 25 , with $\mu v \rho[1] \alpha \omega v$, 'thousand', then finally decides also to avoid the repetition

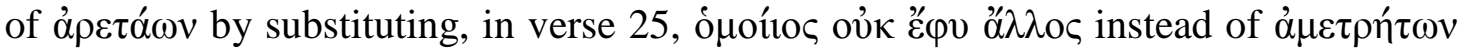
$\alpha \rho \varepsilon \tau \alpha$ av, which completely modifies the construction of this verse and the one preceding it.

- In order to correct an oversight (most often haplographies), he inserts or adds above the line the letter or word omitted, very rarely with an insertion stroke.

- In order to change the order of verses in the way they were presented in the first draft, he places before each a letter of numerical value to re-establish the order he wishes. ${ }^{39}$

The modifications also consist of inserting new material: Dioscorus does this between lines (verses $2,5,7$ ) or in the margin at the height at which he wishes to make this insertion (verses $3,9,15,20$ ). When he adds several verses at the same time (this can be up to nine) ${ }^{40}$ it is not possible for him to do so in between || lines, and he therefore uses the margins by signalling with a symbol the place of insertion. When his sole purpose is not to 'inflate' the poem by developing the material or the idea of the verse after which he wishes to place an insertion (what I would call an 'ornamental' addition), the addition aims to correct the omission of a compulsory or expected rhetorical topos (a 'functional' addition). One sometimes has the impression that, the first draft completed, Dioscorus re-read his poem by comparing it to the recommendations of rhetorical handbooks, perhaps even the famous late antique handbook by Menander Rhetor, which one of his poems seems to prove he knew directly. ${ }^{41}$ The epithalamion for Callinicus is a good example of this: while re-reading his poem, Dioscorus must have realised that he had neglected the bride in favour of the groom. Even if the latter, thanks to his eminent position as duke of the Thebaid, is the one who truly interests him, he must however praise the wife in the same way as the husband in a eulogy which is at times combined with

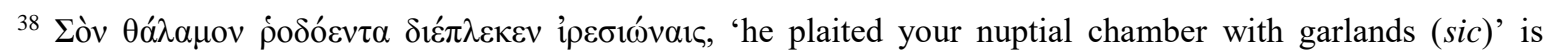

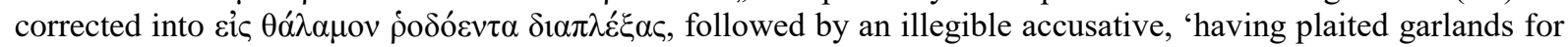
your nuptial chamber [...]'.

${ }^{39}$ P. Aphrod. Lit. IV 33, 1-7. This use is attested in the diorthosis of manuscripts up until the medieval period.

${ }^{40}$ P. Aphrod. Lit. IV 10, 23-31.

${ }^{41}$ P. Aphrod. Lit. IV 7, 5-7 and the commentary on it I have proposed. One notices in fact many parallels between the whole of his poems and Treatise II (cf. Hellénisme, II, thematic and general index, see entry Menander Rhetor). We know that the work of this rhetor was circulating in proto-Byzantine Egypt thanks to a letter edited by H. Maehler, 'Menander Rhetor and Alexander Claudius in a Papyrus Letter', Greek, Roman and Byzantine Studies, n. 15, 1974, p. 305-12. 
that of her husband, other times independent. Thus he adds verses 2, 3 and 5 to bulk up the eulogy of the bride alone, and verse 7 to increase the combined eulogy.

It should be noted that many verses inserted are borrowed from previous poems and are part of a stock from which the poet likes to draw. Here we are touching one of the salient features in the poetic work of Dioscorus: the process of citation and self-citation. ${ }^{42}$ Dioscorus often borrows from others: most often expressions comprised of two or three words (hemistichs, clausulae), sometimes a whole verse, and exceptionally a whole stanza. ${ }^{43}$ One detects here the influence of the authors that have made a mark on him the most: Homer, Nonnos, and PseudoApollinarius of Laodicaea for hexameter, Menander and Euripides for trimeter. But it must be acknowledged that borrowing is not a process specific to Dioscorus. Borrowing without citing one's source was never perceived in antiquity as plagiarising or even as a lack of originality. The demands of meter and prosody in ancient verse often condition what one could call an automatic borrowing from established models. Proto-Byzantine poetry has even made a system out of this with the cento, a type of poem entirely composed of citations, for which the two most famous examples || are the Christus Patiens attributed to Gregory of Nazianzus (cento of Euripides) and the Homeric Centos of the empress Eudocia.

Of greater interest is the constant use by Dioscorus of verses borrowed from his own poems, sometimes word for word, and at other times modified according to methods that this is not the place to develop, but that are characteristic of the rhapsodic patchwork that often serves as composition work in Dioscorus. ${ }^{44}$ Some of his poems go as far as giving the impression of being mere successions of verses taken from here and there and added to each other in a paratactic manner. In fact, in so much as - as we have seen - a verse by Dioscorus often corresponds to a topos of encomiastic rhetoric, one must see there the influence of the acclamation genre, a form of eulogising expression very trendy in the Byzantine period based on the almost incantatory repetition of short formulae submitted to strict codes, where all originality is proscribed. I mostly believe that the process of self-citation is to be explained by the very nature of Dioscorus' poetry: far from wanting to create a work destined for posterity, according to his needs and the circumstantial constraints, he composes poems that each address a different figure from whom he is seeking to obtain some support. These can without too much inconvenience combine together elements used in pieces previously sent to others. This is why it seems to me this principle of pragmatic economy can best explain this phenomenon of selfcitation and shows us once more the practice of literature under an essentially functional light.

This utilitarian dimension finally allows us to account for another process at work in Dioscorus' poetry: translation. ${ }^{45}$ Indeed one often has the impression that his poems have not been thought out in verse, but that they are often following a model or framework in prose. This is not solely due to the predominance of the rhetorical models we have mentioned but also to the nature of part of Dioscorus' works, those resembling petitions. ${ }^{46}$ Petitions are a type of regulated document that seems to have seeped into many of Dioscorus' poems to the point that one could consider them as verse translations of petitions. One finds there not only the same plan (prooimion, justification of the petition, conclusion according to which the petitioner asks help from the authority he is addressing and thanks it in advance) but also the same vocabulary and expressions, adapted to the demands of verse. Sometimes the reality that is expressed is so prominent that it imposes itself without modification: hence Dioscorus' poems are riddled with prosaic or even technical words, that are in stark contrast with the archaic flavour of the

\footnotetext{
${ }^{42}$ Hellénisme, I, p. 297-311.

${ }^{43}$ Whole verse: Menander, Dyscolos, $969=$ = . Aphrod. Lit. IV 10, 16; Nonnos, Dionysiaca, II $579=$ P. Aphrod. Lit. IV 41, 5 (slightly modified). Stanza: Anacreontea, 45, 1-4 = P. Aphrod. Lit. IV 39, 9-12.

${ }^{44}$ Hellénisme, I, p. 305-9.

${ }^{45}$ Hellénisme, I, p. 312-16.

${ }^{46}$ P. Aphrod. Lit. IV 1-16, at least. On petitions, see below.
} 
Homeric meter and the corresponding poetic vocabulary. The nature of Dioscorus' poetry was to have a practical purpose, which conditioned its compositional mode as much as it shaped it. ||

Dioscorus does not only translate prose into verse, but also one type of meter into another. The most accomplished poetic structure in Dioscorus is the poem in dactylic hexameters preceded by a prologue in iambic trimeters, a very fashionable style in the proto-Byzantine period. ${ }^{47}$ It seems that Dioscorus was taking as his starting point one of either part to compose the other, reproducing each theme in a different meter. In the majority of cases, however, his rough drafts show us that he would start with the hexameter part and finish with the prologue in trimeters. This inversion in the order of composition, that allows us to enter very concretely into the poet's 'laboratory', can perhaps be attributed to school instructions that recommended starting with the body of the poem itself, of more delicate craftsmanship since it is written in epic verse, before tackling the prologue written in a verse more similar to prose and whose theme refers to the part in hexameter. At any rate, the fact that the prologue becomes a copy of the body of the poem itself, so much so that it is sometimes just as long, seems to me symptomatic not only of Dioscorus' almost mechanical processes in his composition, that pertain to the utilitarian nature of his poetry, but especially of a deep change in the social conditions in poetic practices. Occasional poetry was, in antiquity and in particular during the imperial period, a publicly performed type of poetry. It is within this context that the prologue must be understood, since its primary function was to establish contact with the audience that one is trying to exert a captatio benevolentiae on. The new shape it takes in Dioscorus - but also in his contemporary poets - tends to show that his poetry, probably like that of many other minor poets, had lost its oral dimension and that it.was reduced to compositions that were either sent or presented in written form. Here is something that could be revealing of a more polyvalent usage of poetry, liberated from that point forward from the traditional conditions of enunciation, which is not without consequences for its evolution, but also, as we shall see later, for the place and practical function of literary practice in late antique society.

\section{THE PRACTICE OF 'COMPOSITION WRITING'}

The interest of Dioscorus' autographs is not limited solely to the process of poetic elaboration that they allow us to witness in progress. Before being a poet, Dioscorus is a writer: what his autographs illustrate is the practice of a type of writing I would call 'non-quotidian' (in contrast with writing pure documents). Papyri throw light in particular on the copying work of literary texts, that is, on editing and reproducing; they do not document the elaboration and composition work outside of the documentary context. However, one could legitimately wonder if 'copywriting' is exposed to the same rules and demands that 'composition II writing' is; if 'composition writing' varies according to whether the text is literary or documentary. In short, how did one write literature in the sixth century A.D.?

The act of writing starts by the choice and positioning of the material, in this case papyrus, since Dioscorus does not use any other. ${ }^{48}$ The majority of his poems have been composed on already-used folios: the poem is sometimes written on the back of a papyrus the front of which has been used for the composition (temporary or definitive) of a document, sometimes, in the case of longer rolls, in the middle of various documents (plate 3). In rarer cases, Dioscorus uses a blank roll, but one can wonder then if it is not the definitive state of the text or the copy sent, that, for reasons that escape us, would have remained in the possession of the author. At any rate, as a whole, one has the impression that the composition of literary texts was not conceived as drastically different from that of documentary texts, since the two could coexist on the same papyrus.

\footnotetext{
${ }^{47}$ Hellénisme, I, p. 278-83.

${ }^{48}$ For more details, see my Hellénisme, I, p. 241-5.
} 
The way in which these poems are materially inscribed on the papyrus sheet manifests some permanent features that are revealing of trends or Dioscorus' own preferences and perhaps, through him, of writers of his period. In as much as a papyrus folio presents on one side horizontal fibres and on the other side vertical ones, the writer has the choice of which side to write on (along the fibres or across the fibres) unless, obviously, in the case of a codex where both sides of the folio are being used. An arrangement of the papyri based on the relation between the direction of the fibres and that of writing shows very clearly that, whenever possible, our poet writes on a folio whose fibres run vertically, despite the relative inconvenience that inhibits the progression of the reed pen across the fibres (which explains, it seems, the habit of copyists of writing on the side of the roll where the fibres run horizontally). I would be tempted to see in this the influence of a documentary practice that, in the Byzantine period, privileges writing transversa charta (that is, on a roll turned around vertically so that the fibres run vertically).

Four poems escape this rule: in two cases, ${ }^{49}$ it is likely that here one is dealing with definitive copies, something that encourages us to wonder if there is a causal relation between the status of definitive copy and the text running along the fibres.

Such a presentation could indeed be perceived as more adapted to literary texts in as much as it contrasts with the documentary usage, and it belongs to a long editorial tradition of copying along the fibres of the roll which, in a period where it was definitely replaced by the codex, could benefit from the prestige of being archaising.

This explanation could also be given for the other two exceptions, ${ }^{50}$ but I would be tempted to justify them differently. In the case of those two poems, we are dealing here with genuine versified petitions, and it is no coincidence that they adopt precisely the same presentation as the prose petitions of Dioscorus, that $\|$ is, as opposed to the majority of the other documentary genres, going along the fibres. These two exceptions would reveal therefore the influence of documentary practice on the writing of literature at the same time as on the particular status of petitions, a documentary genre situated at the fringe of literature. II

At any rate it is apparent how the sole positioning of the writing material in one direction or another is conditioned by usage which itself depends partly on the content. If Dioscorus, in his rough drafts, is affected by documentary practice - to which he must have devoted most of his time -, it is likely that the finished copies of his poems followed the rules for copying literary texts. The case of petitions demonstrates in spite of everything that there is not always ground for opposing literary practices to documentary ones.

Once the material is chosen and oriented, the writer is confronted with another choice: that of the script, or rather the style of script. It is a known fact that the script of literary texts is normally not the same as that of documents and script varies from one genre to another (letters, contracts, accounts). We actually have in the hand of Dioscorus documentary texts as well as literary ones, and among the latter, texts of which he is the author and others that he merely copied; he offers the richest dossier for the study of writing styles. ${ }^{51}$

Dioscorus normally uses two main styles of writing that show a system based on oppositions in terms of the ductus of letters as well as their inclination: a sloping uncial for literary texts and a vertical cursive for documentary texts (plate 3). In fact, Dioscorus' literary hand could also show variations in its inclination, which, in a way, is based on this system of oppositions: it happened sometimes that his literary hand was vertical. But it is no coincidence if this vertical orientation is encountered in the prose prologue of a poem in trimeters written itself in a sloping style. ${ }^{52}$ And in as much as there existed a difference in poetic degree between

\footnotetext{
${ }^{49}$ P. Aphrod. Lit. IV 4 (Romanos' eulogy) and 11 (eulogy for the adventus of duke John).

${ }^{50} P$. Aphrod. Lit. IV 1 and 2.

${ }^{51}$ Hellénisme, I, p. 245-8.

${ }^{52}$ P. Aphrod. Lit. IV 47.
} 
a prologue in trimeters and a poem in hexameters - which is related not only to the traditional function of a prologue, but also to the nature of the trimeter, a verse close to prose - one is not any more surprised either that a particular prologue in trimeter is of a more vertical hand than the poem in hexameter it introduces ${ }^{53}$ or even that poems made entirely of iambic verses are written in this vertical style. ${ }^{54}$ Even though it is not systematic, it is possible to detect a close, functional relation between style of writing and textual content, specifically between the inclination of writing and the poetic degree given to the text.

The tracing and inclination of letters is not sufficient to account for a hand. There is no such a thing as 'pure' writing, at least not in this period. Indeed in addition to letters, there are also lectional signs or 'prosodic' marks as the ancients called them, whose purpose is to compensate for the ambiguities caused by the use of scriptio continua. This whole range of marks evolves according to the period and differs according to the context of writing, as well as the function and genre of the text. Dioscorus' autographs can also be compared here with other literary texts, and, even more interestingly, with contemporary documentary texts, even by the $\|$ same hand. This allows us to answer the question of whether there was a difference between 'composition-writing' in the literary realm and in the documentary realm. In fact one notices that, aside from the macron (a stroke signalling the length of the three quantatively undetermined vowels $\alpha, 1, v$ ), all the lectional signs used in the composition of his poems (accents, breathings, diaireseis, apostrophes, supralinears) can be found in his documents, often in the same proportion and in identical frequencies. Dioscorus does not distinguish therefore a documentary practice from a literary practice; on the contrary, both follow the same rules that have become automatic, and are considered as two sides of the same activity: writing.

Therefore the study of literary practices must go beyond the limits of literature, stricto sensu (whether it is read or created) and expand into the realm of documents that provide evidence which, although underestimated, is enlightening in many ways.

\section{DIOSCORUS THE NOTARY: THE INTERMINGLING OF DOCUMENTS AND LITERATURE}

During his forced stay in Antinoopolis Dioscorus practiced the office of notary. At his arrival in the capital of the Thebaid, he addressed a poem to the civil governor (the praeses Victor) which he concluded with this request: 'grant your servant a position as a notary in the city'. ${ }^{55}$ The many rough drafts of legal documents by his hand (plate 3) seem to demonstrate that the governor granted his request. However, the fact that it is thanks to a poem that Dioscorus became a notary, or at least that his poetic skills, even if they could be deemed limited in comparison to the great masters of poetry, earned him this position, far from being anecdotal or the result of a coincidence, reveals a cultural phenomenon characteristic of late antiquity: the permeability between the realm of literature and the notary and legal realm, and thus that of civil service. The latter is in fact summed up by the ambiguity of the title of scholastikos (held by Dioscorus) that indicates both a man of letters and a man having received a legal education. ${ }^{56}$ Dioscorus confirms this in his verse eulogies in which the recipient, if he is a civil servant, is constantly compared to the great figures of literature, real (Homer, Menander) or mythological (the Muses, Orpheus), as if the ideal civil servant was a poet. ${ }^{57}$ And it is a fact that the highest positions in the administration, far from being the privilege of only the technicians of law and administration, were often granted to men of letters and especially to poets such as Andronicus

\footnotetext{
${ }^{53}$ P. Aphrod. Lit. IV 14.

${ }^{54}$ P. Aphrod. Lit. IV 12, 23, 38.

${ }^{55}$ P. Aphrod. Lit. IV 12, 32.

${ }^{56}$ Cf. A. Claus, $\Sigma \chi 0 \lambda \alpha \sigma \tau \iota \kappa o ́ \varsigma$, diss. Cologne, 1965. Dioscorus held this title in P. Cair. Masp. I 67064, 13-14.

${ }^{57}$ Hellénisme, I, p. 339-41.
} 
(fourth century), Claudian (fourth-fifth century), Olympiodorus I| (fifth century), Cyrus (fifth century), and Pamprepius (fifth century) - to cite only Egyptian poets similar to Dioscorus. ${ }^{58}$ In this process there is a double phenomenon at work that is fundamental in order to sufficiently grasp literate practices in the proto-Byzantine period in all of their complexity.

\section{THE 'LITERARISATION' OF DOCUMENTS}

Starting from the fourth century A.D. one witnesses the influence of literature on documents growing deeper and deeper, as well as the increase of the influence of literary education and practice on the manner in which one composes a notarised contract or a document in general. This is what I would call the 'literarisation' of documents. Of course, it is understood that rhetoric was having a growing impact on number of documentary genres, such as petitions, since their goal was to convince. But this influence of literature goes even further with the increasing effect of poetry on documents. This phenomenon was felt the more strongly in that it was opposed to the thousand-year-old tradition of Atticism as a model for prose. Citations or paraphrases of known poets invaded documents; the precious vocabulary of poetry crept under the reed pen of notaries more and more often. ${ }^{59}$ The notarial documents of Dioscorus are excellent examples of this. Even when he is a notary, Dioscorus continues to be a poet; this is the case in the majority of his petitions. The petition, a text with which a subject informs an authority of an offence he was the victim of and for which he requests compensation, often starts in this period with a very well-crafted introduction where the virtues of the official being addressed are praised in a genuine enkomion, highly influenced by the strictures of Greek rhetors. ${ }^{60}$ Furthermore, the imprint of poetic literature can be observed throughout the whole text with the vocabulary used, sometimes with the citations (whether literal or adjusted), or with echoes that betray a literary influence that had become an automatic reflex. ${ }^{61} \mathrm{II}$

This literary influence runs so deep that it can be felt in the most formulaic and technical documents, with concrete, objective content (as opposed to petitions that play with a certain amount of pathos) such as, for example, a contract of shared inheritance composed by Dioscorus, in which he uses, against all expectations, the Homeric form oúvo $\mu \alpha$ instead of övo $\mu \alpha .{ }^{62}$ More than an indication of his frequent reading of Homer or more generally of epic poetry (that we already knew about thanks to his library and his own works), this example indicates more specifically the importance of poetry in the composition of any sort of document.

Literary culture does not merely impose its imprint on the language or content of documents: it affects also their written form, a symptom that demonstrates the importance and intensity of this phenomenon, especially as it has the character of an automatic reflex. The proto-Byzantine period indeed saw the widespread habit of using, in the composition of some types of documents, lectional signs that were up until then reserved exclusively for the copying

\footnotetext{
${ }^{58}$ Alan Cameron, 'Wandering Poets: A Literary Movement in Byzantine Egypt', particularly p. 497-507.

${ }^{59}$ H. Zilliacus, Zur Abundanz der spätgriechischen Gebrauchssprache, Helsinki, 1967, p. 68-83.

${ }^{60}$ Cf. H.J. Frisk, Bankakten aus dem Faijûm nebst anderen Berliner Papyri, Gothenburg, 1931, p. 78-91; J.-L. Fournet, 'Notes critiques sur des pétitions du Bas-Empire', Journal of Juristic Papyrology, n. 28, 1998, p. 718, and particularly p. 9-11; id. 'Entre document et littérature, la pétition dans l'Antiquité tardive', in J. Gascou and D. Feissel (eds.), La pétition à Byzance, Paris, 2004, p. 61-74.

${ }^{61}$ Cf. in general, A.B. Kovelman, 'From Logos to Myth: Egyptian Petitions of the 5th-7th Centuries', Bulletin of the American Society of Papyrologists, n. 28, 1991, p. 135-52; and, in particular, the study of a petition composed by Dioscorus (albeit not written by him), containing a quotation of the Iliad and various poetic words and expressions, in J.-L. Fournet, 'À propos de SB XIV 11856 ou quand la poésie rencontre le document', Bulletin de l'Institut francais d'archéologie orientale, n. 93, 1993, p. 221-35, particularly p. 221-7. I give other examples in my Hellénisme, II, p. 673-5 (Homer), 677 (Menander), 678, n. 47 (Euripides?), 679 (Nonnos). See also, ibid. p. 684, n. 82.

${ }^{62}$ P. Cair. Masp. III 67314, III 7-8.
} 
or study of literary texts, mostly poetic (accents, breathings, punctuation) ${ }^{63}$ Dioscorus offers many examples of this in his notarial deeds. And it is no coincidence that in his archives that contain documents written by many other hands than his own, it is from his pen that one finds the highest proportion of diacritics borrowed from books: it shows how much this new way of writing was the reflection of the literary education of a writer, and especially how much literary practices took over the area of daily writing.

This phenomenon of 'literarisation' of documents goes so far that genres considered up to then as purely documentary begin penetrating the realm of literature: letters, of course, the status of which had been ambiguous already for a long time, and that the proto-Byzantine period is going to take more and more towards literature, but also petitions, as we have just seen, become pieces of literature and claim openly for themselves a literary status to the point that they start being copied and diffused in the same respect as literary works. ${ }^{64}$ This is how one can explain the collection of documentary pieces compiled by Dioscorus that found a place in his library, containing two letters and a petition by the $\|$ famous philosopher Horapollo (fifth century A.D.), the author of a treatise on hieroglyphs. ${ }^{65}$

\section{THE 'DOCUMENTARISATION' OF LITERATURE}

The opposite process can also be observed. We have seen earlier how the great works of literature had been reclaimed for practical purposes, being used not only as models for pupils at school, but also as handbooks for professionals in the expertise of speaking and writing. Even better, literary creation can also be made to serve documentary practice: Dioscorus does not hesitate to attribute to poetry the established role of documents. As different pieces in his corpus confirm, he composed poems to accompany the petitions he submitted to the authorities; they resembled versified doubles of his requests in prose which they enhanced with the lustre of their poetic form. The poem thus becomes the auxiliary of the document. We are witnessing here a unique phenomenon or, more precisely, one that is documented only by Dioscorus' dossier, but which one can assume was more widespread. ${ }^{66}$ It at least casts a new light on literary practices in this period.

Dioscorus revealed himself throughout these pages as a perfect paradigm of literate practices in late antiquity in its widest sense. The man of letters is above all a man of writing, even more so in this period than in previous times where the relationship between man and literature reading, composition, publication - essentially went through speech. We have also seen how rich with lessons the more material dimension of writing was: the poetic rough drafts of Dioscorus as much as his notarised contracts constantly confirm the necessity not to dissociate paleographical data traditionally considered as external, formal or contingent - this is how palaeography is often treated - with regard to the content. The positioning of the writing material, the style of writing and the use of some lectional signs are directly in symbiosis with the textual content itself. The writing and presentation of the latter are not solely an external adornment but they convey a part of the meaning at the same time as they reflect the cultural choices of a period. In short, the palaeographical or codicological fact, when interpreted well,

${ }^{63} \mathrm{I}$ have analysed this phenomenon in 'L'influence des usages littéraires sur l'écriture des documents: perspectives', Proceedings of the 20th International Congress of Papyrologists, Copenhagen, 1994, p. 418-22, and I have shown that the usage for these accents is linked to the teaching of Homeric poems in 'L" "homérisme" a l'époque protobyzantine: l'exemple de Dioscore d'Aphrodité', Ktema, n. 20, 1995, p. 313.

${ }^{64}$ Collections of letters start developing in this period. For an example of a petition with a literary posterity, cf. J. Gascou, 'Les privilèges du clergé d'après la "lettre" 104 de S. Basile', Revues des sciences religieuses, n. 71/2, 1997, p. 189-204. We saw earlier how the subliterary status of petitions could be translated in the layout of the page.

${ }^{65}$ P. Cair. Masp. III 67295, n. 14 in the list of works of Dioscorus' library given previously.

${ }^{66}$ Hellénisme, I, p. 259-64. 
is much more than a pure material or physical fact: it is a cultural microcosm in its own way. And I think that we owe to the Byzantines the development of this acute awareness of how meaningful the graphical aspect was, which introduced a diversification of the range of writing modes.

If it confirms this significant diversity of writing modes, the palaeographical study of Dioscorus' papyri does not attest a differentiation between literature and document, despite the two modes of expression being in principle opposed in their nature and function. On the contrary, the points of contact between literary practice || and documentary practice are so numerous in Dioscorus' dossier that they seem rather to reveal a unified notion of writing, where literature and documentation do not necessarily belong to two impenetrable spheres, since their form and purpose could meet each other. This unified notion of writing, far removed from ours, that orders the scope of use for writing and language according to the area and function, is the sign of a society that has raised high literature to a universal value and competence and that, aside from a naturally growing trend that the orator Libanius bemoans in the fourth century A.D. ${ }^{67}$ refuses in the end to separate technical know-how and literary culture. This indicates a society steeped in culture, where administrative, political, and even private action cannot be conceived without high literature and particularly poetry, an idealised mode of expression. This translates at the same time, according to a trend which is not specific to the Byzantine period but which reinforces itself then, into a functional notion of literary culture, which is reclaimed and made instrumental at all levels (for the schoolmaster, the reader in his library, the orator-poet or the notary-civil servant) and which, at the opposite end of the spectrum from an extraneous and playful artistic state, is meant to serve public and private action. Whatever literature loses in independence or elevation, the document gains in quality. And finally, this intensity and omnipresence of literary practice and the variety in its manifestations compensate a little for the impoverishment of literary inheritance and the decrease in editorial activity that one rightly notices in this period and in which it is customary to detect the signs of a decadence of Greek culture.

Abbreviations

Hellénisme = J.-L. Fournet, Hellénisme dans l'Égypte du VIe siècle: la bibliothèque et l'œuvre de Dioscore d'Aphrodité, Mémoires de l'Institut français d'archéologie orientale, 115, Le Caire, 1999.

P. Aphrod. Lit. $=$ papyri published in Hellénisme.

P. Cair. Masp. = J. Maspero, Papyrus grecs d'époque byzantine. Catalogue général des antiquités du musée du Caire, I-III, Le Caire, 1910-1916.

Bibliographical additions since 2005

J.-L. Fournet (ed.), Les archives de Dioscore d'Aphrodité cent ans après leur découverte. Histoire et culture dans l'Égypte byzantine, Coll. 'Études d'archéologie et d'histoire ancienne', Paris, 2008.

J.-L. Fournet, 'Le poète Dioscore d'Aphrodité à l'œuvre: une première version de P.Aphrod. Lit. IV 18, enkômion d'adventus du duc Kallinikos', in R. Ast, H. Cuvigny, T.M. Hickey and J. Lougovaya (eds.), Papyrological Texts in Honor of Roger S. Bagnall, Durham, 2012, p. 97 106.

\footnotetext{
${ }^{67}$ For example, Or., XXVI, 51 (where Libanius bemoans that Constantius II named hypographeis rather than orators for prefects). See also Or., XLII, 23-5.
} 
[p. 227] Plate 1 A folio of Dioscorus' Iliad (book II, 556-76) where one can observe the diorthosis work: the addition of an athetised verse in the upper margin with a reference mark, the correction of an erroneous reading in line 4. Egyptian Museum of Cairo. Photograph: Prof. Adam Bülow-Jacobsen

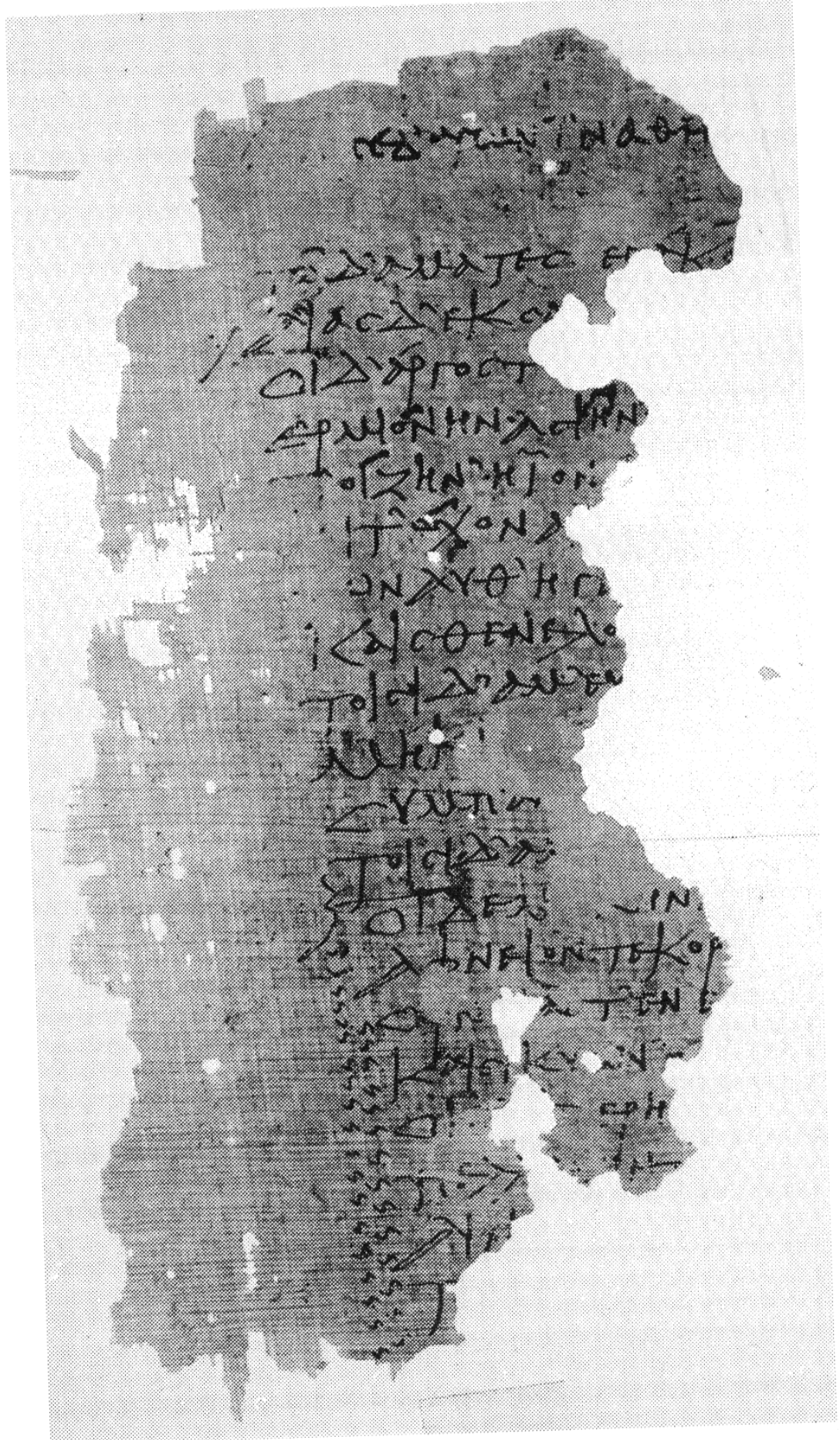


[p. 235] Plate 2 Epithalamion for Callinicus.

Egyptian Museum of Cairo. Photograph: Prof. Adam Bülow-Jacobsen

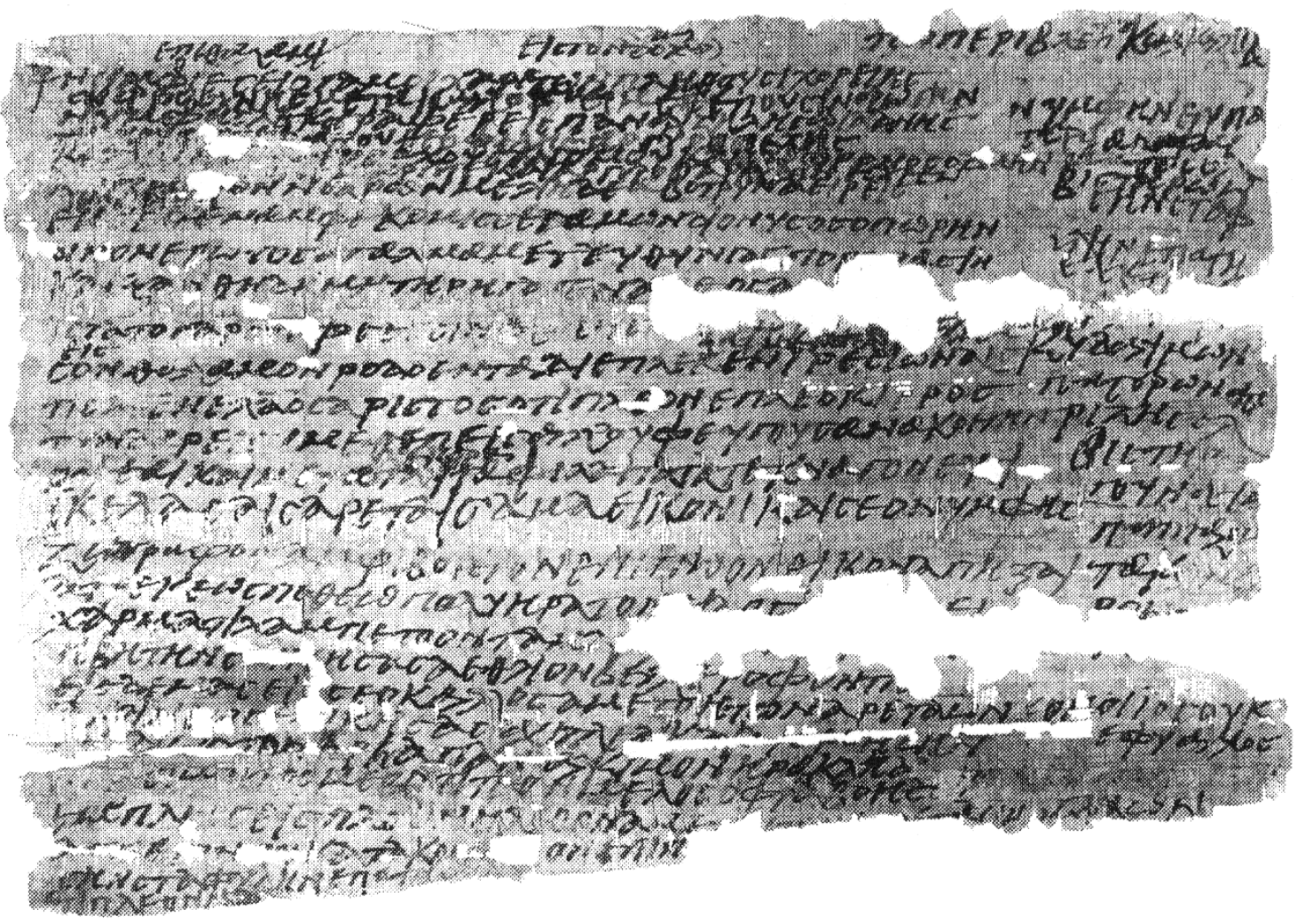


[p. 242] PLATE 3

Part of a roll containing at the top a legal document (upright handwriting) and at the bottom two poems (sloping handwriting), both in Dioscorus' hand.

Egyptian Museum of Cairo. Photograph: Prof. Adam Bülow-Jacobsen

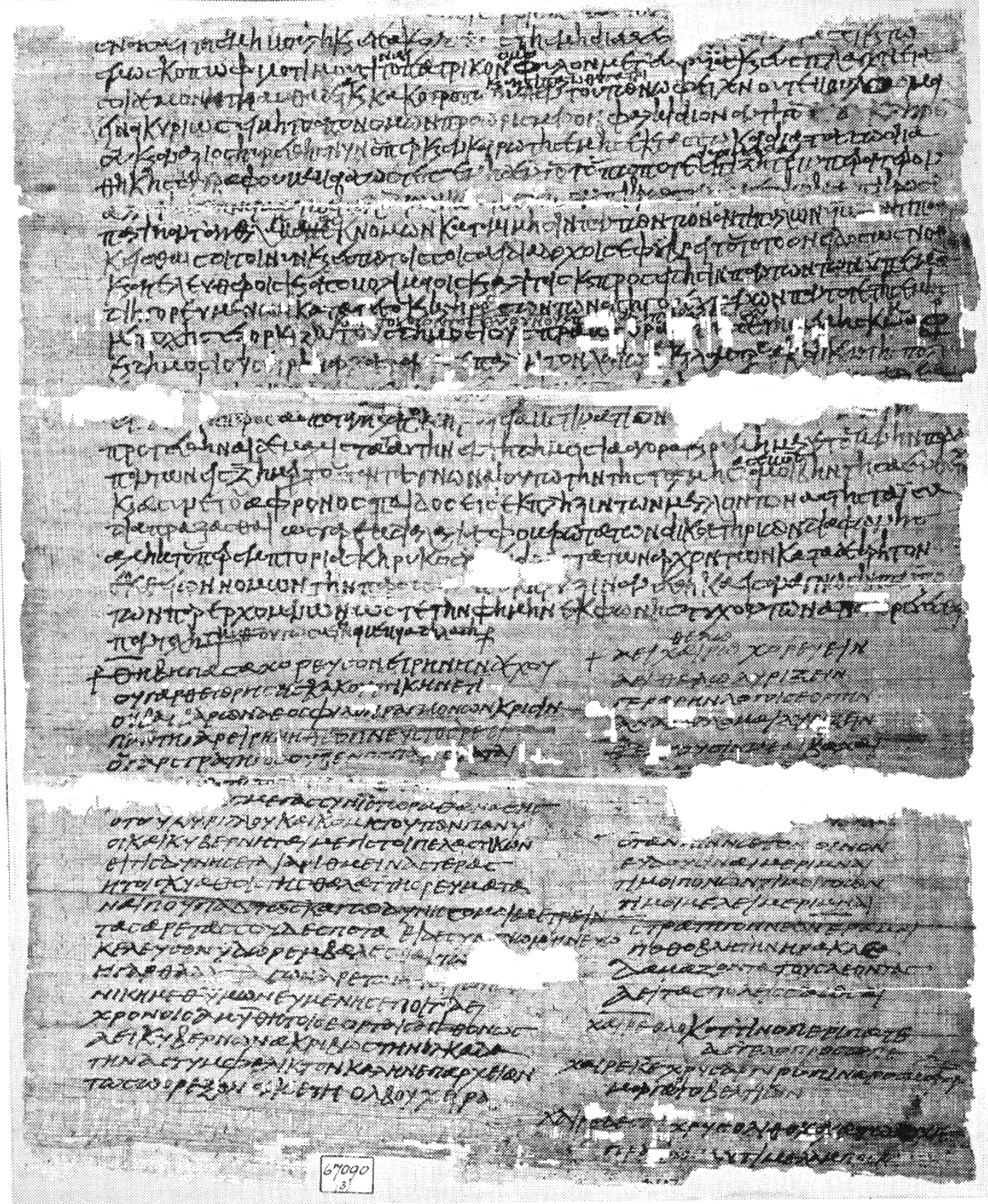

